\title{
Euskal kostaldeko fitoplanktona eta bere garrantzia bibalbioen akuikulturan
}

\author{
(Phytoplankton in coastal waters of the Basque Country and its \\ importance in bivalve aquaculture)
}

\author{
Jone Bilbao*1,2, Oihane Muñiz ${ }^{3}$, Marta Revilla ${ }^{3}$, José Germán Rodríguez ${ }^{3}$, \\ Aitor Laza-Martínez ${ }^{1,2}$, Sergio Seoane $e^{1,2}$ \\ ${ }^{1}$ Landare Biologia eta Ekologia Saila, Zientzia eta Teknologia Fakultatea, UPV/EHU \\ ${ }^{2}$ Research Centre for Experimental Marine Biology and Biotechnology \\ (Plentzia Marine Station; PiE-UPV/EHU) \\ ${ }^{3}$ AZTI, Marine Research, Basque Research and Technology Alliance (BRTA)
}

\begin{abstract}
LABURPENA: Akuikulturak azken hamarkadan mundu mailan izan duen garapena itzela izan da, eta horrek Euskal Autonomia Erkidegoan (EAEn) moluskuen akuikultura gauzatzeko nahia piztu du. Gaur egun, muskuiluak ekoizten berriki hasi den akuikultura-eremu bakarra dago EAEn, itsaso zabalean, Mendexako kostaldearen aurrean. Hala ere, sektorea gehiago garatzeko helburuz, beste aukerazko kokaleku batzuk planteatu dira, Mutrikuko portua adibidez. Gauzak horrela, ezinbestekoa da eremu horretako fitoplanktonaren azterketa sakona egitea, bibalbioen energia-iturri eta, aldi berean, gizakiongan toxikotasun-eragile nagusia baita. Azken urteotan, Mendexan eta Mutrikun, bibalbioen akuikulturarekin erlazionatutako fitoplanktonaren zenbait ikerketa gauzatu dira, bertako komunitate naturalek bibalbioen akuikulturari eusteko duten egokitasuna ezagutzeko asmoz. Ikerketa horietan fitoplankton-komunitatearen ugaritasuna eta osaketa aztertu ziren, potentzialki toxikoak ziren taxonei arreta berezia eskainiz. Horrez gain, muskuiluen haragian aurkitutako toxina-kontzentrazioa ere neurtu zen. Diatomeoak eta haptofitoak izan ziren Mendexako eta Mutrikuko komunitate fitoplanktonikoen talde nagusiak, dinoflagelatuen aldizkako agerpenekin batera. Horrenbestez, fitoplankton-komunitate horiek muskuiluen hazkuntzarako kalitate nutrizional onuragarria daukatela ikusi da, talde nagusiek gantz azido maila altuak azaltzen dituztelako. Gainera, komunitateetan nagusitzen zen zelula-tamaina $(2-20 \mu \mathrm{m})$ aproposa da muskuiluen ingestio eta erretentzio eraginkorrerako. Hala ere, Europako beste akuikultura eremu batzuekin alderatuz, Mendexako eta Mutrikuko $a$ klorofila-balioak oso baxuak dira, $0,5 \mu \mathrm{g} / \mathrm{L}$ inguruko kontzentrazioekin. Halaber, itsaskien toxikotasun-arriskua adierazten duten zelula-ugaritasuna eta toxinen kontzentrazio-mugak hainbat aldiz gainditu ziren bi eremuetan. Dinophysis da generorik arriskutsuena, Mendexan bereziki, genero horren eta bere toxinen (azido okadaikoa) kontzentrazioa handiagoa baita. Horrenbestez, beharrezkoa da fitoplanktonen azterketekin jarraitzea, toxikotasun-arrisku posibleak hauteman eta kontrolatzeko.

HITZ GAKOAK: bibalbioen akuikultura, fitoplankton-komunitatea, toxikotasun-arriskua.
\end{abstract}

ABSTRACT: Lately, aquaculture has undergone a great development worldwide and, in the Basque Country, there is an increasing interest for developing it. Nowadays, there is an offshore aquaculture site in Mendexa, which started producing mussels recently. Alternative locations have been discussed to continue developing the sector, such as the port of Mutriku. In this context, studying the phytoplankton community is essential, since it is the main source of energy for bivalves and the main potential toxicity risk. In the last years, several studies on the suitability of the phytoplankton communities from Mendexa and Mutriku as a food resource for bivalves have been carried out. For that, phytoplankton community composition and biomass were analyzed, paying special attention to toxic taxa and concentrations of toxins in mussel flesh. Diatoms and haptophytes, together with dinoflagellates, were the most important groups at both stations in terms of abundance and/or biomass, which could favor mussel growth due to high fatty acid content. Moreover, the predominant cell size of the comunities $(2-20 \mu \mathrm{m})$ would enable an efficient ingestion and retention for mussels. However, chlorophyll a waslow at both sites comparing with other aquaculture areas in Europe, with an average concentration of $0.5 \mu \mathrm{g} / \mathrm{L}$ approximately. Regarding shellfish toxicity, alert limits were exceeded several times, being Dinophysis the most compromising genus for Basque aquaculture, especially in Mendexa, where higher cell abundances and toxin concentrations (okadaic acid) of this genus were recorded. Consequently, the phytoplankton monitoring should be carefully conducted in order to detect possible toxicity risks.

KEYWORDS: bivalve aquaculture, phytoplankton community, toxicity risk.

* Harremanetan jartzeko / Corresponding author: Jone Bilbao Antolin. Landare Biologia eta Ekologia Saila, Zientzia eta Teknologia Fakultatea, Euskal Herriko Unibertsitatea, Leioa 48940, Espainia. - jone.bilbao@ehu.eus - https://orcid.org/0000-00029278-1515

Nola aipatu / How to cite: Bilbao, Jone; Muñiz, Oihane; Revilla, Marta; Rodríguez, José Germán; Láza-Martínez, Aitor; Seoane, Sergio (2021). "Euskal kostaldeko fitoplaktona eta bere garrantzia bibalbioen akuikulturan». Ekaia, 40, 2021, 181-202. (https://doi.org/10.1387/ekaia.22340).

Jasotze-data: 2020, abenduak 11; Onartze-data: 2021, urtarrilak 14.

ISSN 0214-9753 - eISSN 2444-3581 / (c) 2021 UPV/EHU

(i) $\odot$ Lan hau Creative Commons Aitortu-EzKomertziala-LanEratorririkGabe 4.0 Nazioartekoa lizentzia baten mende dago 
Jone Bilbao, Oihane Muñiz, Marta Revilla, José Germán Rodríguez, Aitor Laza-Martínez, Sergio Seoane

\section{SARRERA}

Fitoplankton-komunitatearen osaketak eta dinamikak eragin nabarmena du akuikulturan, moluskuen hazkuntzara zuzendutakoan bereziki; izan ere, bibalbio filtratzaileen (muskuiluak, adibidez) oinarrizko energia-iturria da fitoplanktona [1, 2]. Hori kontuan izanda, eremu bateko fitoplanktonkomunitatearen biomasa-ugaritasuna oso faktore garrantzitsua da bertako bibalbioen hazkuntzarako. Bestalde, komunitate fitoplanktonikoaren osaketa ezagutzea ezinbestekoa da, baita ere, fitoplankton-espezie guztiek ez dutelako kalitate berdina bibalbioen elikagai gisa. Zenbait ezaugarri betetzea garrantzitsua da bibalbioen hazkuntzari begira baliagarriak izateko; hala nola, ingestiorako zelula-tamaina aproposa eta osaketa nutrizional egokia izatea [1].

Muskuiluen ingestio- eta erretentzio-eraginkortasuna fitoplankton espeziearen zelula-tamainaren araberakoa da. Ikerketa batzuen arabera, 35-45 $\mu \mathrm{m}$-ko zelula-tamaina da erabateko erretentzio-eraginkortasuna ahalbidetzen duena [3,4]. Beste batzuek, ordea [5, 6], 15-20 $\mu \mathrm{m}$-ko tartea identifikatu dute erretentzio eraginkorrerako gehienezko tarte bezala. Nolanahi ere, ikertzaile gehienak [7-9] bat datoz erretentzio eraginkorrerako beharrezko neurri-tartea 4-45 $\mu \mathrm{m}$-ko zelula-tamaina dela baieztatzean [4].

Fitoplanktonaren osaketa nutrizionalari dagokionez, elikagai bezala duen balioa konposizio lipidikoaren araberakoa da, bereziki gantz azido esentzialen araberakoa, horiek baitira bibalbio larben energia-iturri nagusia $[10,11]$. Fitoplankton-zelulen osaketa lipidiko hori aldatu egiten da espeziearen edo taldearen arabera. Gainera, hainbat ikerketek frogatu dutenez, alga-espezie ezberdinez (gutxienez, haptofito eta diatomeo mota bat) osatutako dietek espezie bakarrarekin osatutakoek baino elikadura-balio altuagoa dute [11-14].

Hala ere, fitoplankton-espezie batzuk, ingestiorako tamaina eta osaketa nutrizional egokia izan arren, gai dira toxinak ekoizteko. Horrek kalte egiten dio akuikulturari; batetik, muskuiluen hazkundean eragin negatiboa izan dezakeelako eta, bestetik, giza kontsumorako arriskutsua izateagatik muskuiluen komertzializazioa eten behar delako. Deskribatutako fitoplankton-espezie guztien artean (3.000 eta 5.000 espezie-bitartean ur gazitan eta beste horrenbeste ur gezatan), 80 inguru dira toxinak ekoizteko gai [15]. Muskuiluek (eta bestelako bibalbio iragazleek) fitoplankton toxikoa elikagai gisa iragazterakoan, toxinak aktiboki pilatu eta kontzentratu egiten dira haien digestio-guruinean [16]. Horren ondorioz, toxinak maila trofiko altuagoetara transferitzen dira, eta gizaki eta bestelako harrapakarientzako ere arrisku nabarmena bihurtzen, intoxikazioak eragiteko aukera baitago $[17,18]$. Bost dira muskuiluen ingestioaren ondorioz sor daitezkeen pozoidura nagusiak: itsaski-pozoidura amnesikoa (ASP, ingelesez), paralitikoa (PSP), diarreikoa (DSP), neurotoxikoa (NSP) edo azaspirazidoen 
bidezko pozoidura (AZP) [15]. Horien artean, ASP, PSP eta DSP dira gizakien osasuna arriskuan jartzen duten pozoidura ohikoenak. Pozoidura horien atzean hainbat toxina daude, azido domoikoa (ASP), saxitoxina eta goniaulaxtoxinak (PSP), eta azido okadaiko eta dinofisistoxinak (DSP) hain zuzen ere, eta bere ekoizle nagusiak Pseudo-nitzschia, Alexandrium eta $\mathrm{Di}$ nophysis generoak dira, hurrenez hurren. Mundu osoan zehar intoxikazioak ekiditeko prebentzioak eta kalteen arintze-ekintzak martxan jartzen diren arren, ohikoa da konpainia askok denboraldi luzeetan zehar muskuiluen erauzketa eten behar izatea. Gainera, ikusi da fitoplankton toxikoak eragin negatiboa izan dezakeela itsas bibalbioen iragazketan, elikaduran, hazkundean, oxigeno-kontsumoan eta biziraupenean [19].

Fitoplankton toxikoaren agerpen-gertaera berriak eta kaltetutako herrialdeen kopurua nabarmen hazi dira azken urteotan [17]. Gorakada hori elementu naturalek (ekaitzek edo korronteek, adibidez) eragindakoa izan daitekeen arren, hainbat ikerketek harremana aurkitu dute inpaktu antropogenikoaren eta fitoplankton kaltegarriaren gorakadaren artean; nekazaritzak, industriak eta hondakinen isurketek eragindako elikagaien kontzentrazio-hazkundean oinarritzen da harreman hori $[15,17,20]$. Hala ere, harreman hori unibertsala izatetik urrun dagoela frogatu da, eta, gehienetan, kutsadura antropogenikoa fitoplankton-biomasa altuen ondorioz sortutako kalteekin lotzen da, ez biotoxinen ekoizpenarekin [21]. Bestetik, fitoplanktonaren hazkundea eta biotoxinen agerpena aldaketa klimatikoarekin ere erlazionatu dute zenbait egilek [22]. Horrez gain, ontzien lasta-urak eta itsaski stock-aren mugimenduak ere espezie toxikoen dispertsiorako bi eragile garrantzitsu bihurtu dira [23]. Fitoplankton toxikoaren inguruan egindako ikerketa kopuruaren gorakadak eta jarraipen-programen ugaritzeak ere eragin handia izan du; izan ere, haien presentzia leku gehiagotan identifikatzeko aukera eman du, nahiz eta, ziurrenik, betidanik egon diren ber$\tan [23]$.

Akuikultura-produkzioari dagokionez, gorakada nabarmena jasan du azken urteotan (1. eta 2. irudiak). Mundu mailan, 1980an 5 milioi tonako ekoizpena izatetik, 2015ean 77 milioi tona ekoiztera pasatu zen, \% 21a moluskuak izanik. Gainera, 2015ean, moluskuen ekoizpen globala 2006an baino 4 milioi tona handiagoa izan zen (16,4 milioi tona) [24]. Europar Batasunaren baitan, Espainia da muskuilu gehien ekoizten dituen herrialdea, urtean 200 mila tona inguru [25]. Are gehiago, 2015ean, Espainian, akuikultura-ekoizpen osoaren \% 77a (22 5000 t) muskuiluak (Mytilus galloprovincialis) izan ziren [26]. Muskuilu horien \% 95a baino gehiago Galizian ekoizten da, Iberiar penintsularen ipar-mendebaldeko kostaldean [27]. Bertan, egitura flotagarrietan kokatutako soketan hazten dituzte muskuiluak, kostaldeko sarguneetan (ria edo itsasadarretan), non ura azaleratzeko prozesuek eta estuario-zirkulazioak fitoplankton-produkzioa areagotzen baitute $[28,29]$. 
Jone Bilbao, Oihane Muñiz, Marta Revilla, José Germán Rodríguez, Aitor Laza-Martínez, Sergio Seoane

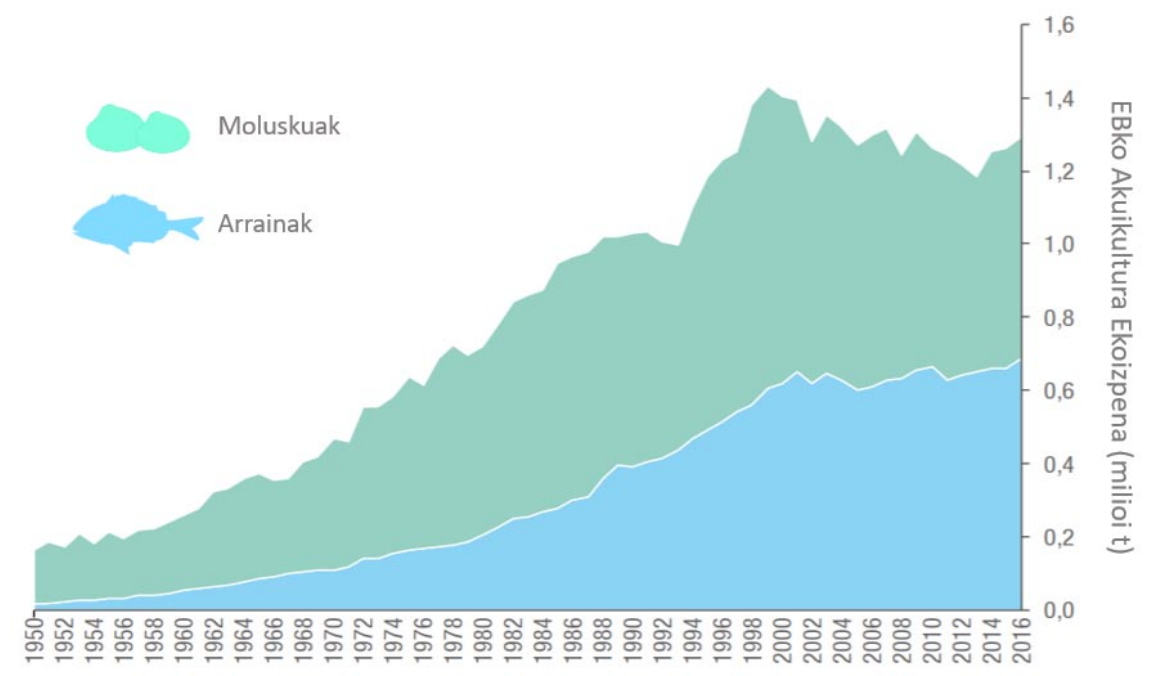

1. irudia. Europar Batasuneko akuikultura-ekoizpenaren eboluzioa 1950-2016 denbora-tartean, FAOren arabera. APROMARetik (2018) eraldatutakoa [30].

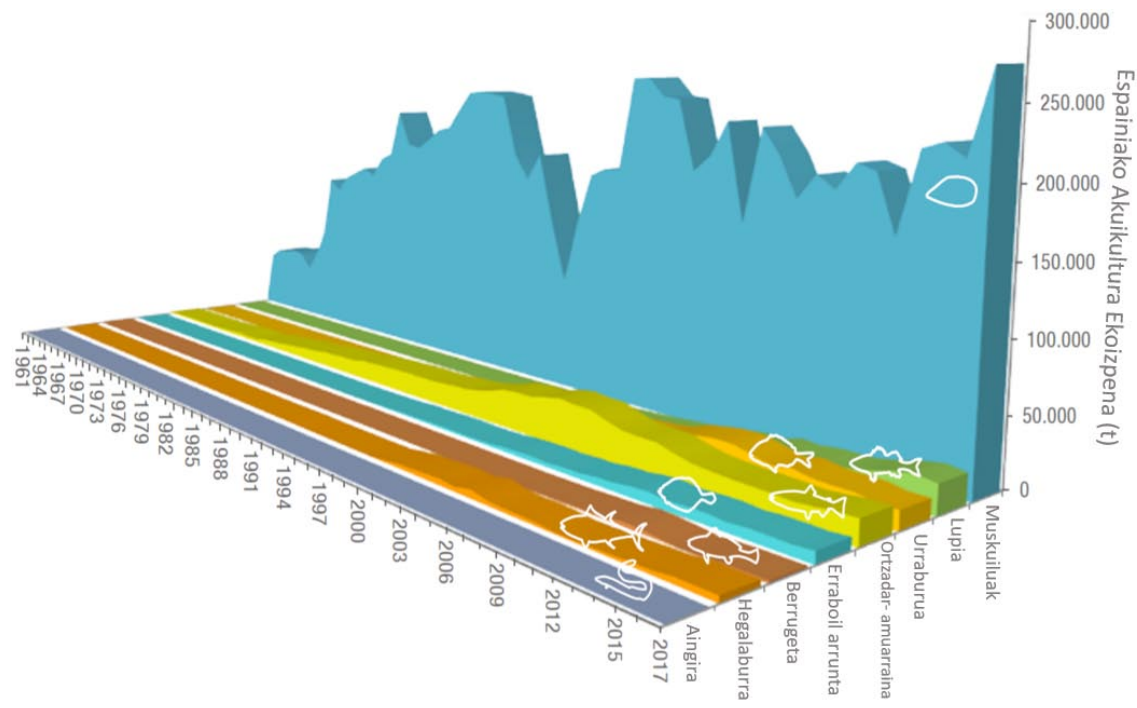

2. irudia. Espainiako akuikultura-uztaren eboluzioa, tonatan, 1960-2017 denboratartean. APROMARetik (2018) eraldatutakoa [30]. 


\section{TESTUINGURUA EUSKAL AUTONOMIA ERKIDEGOAN}

\subsection{Akuikultura EAEn}

Bizkaiko golkoko hego-ekialdean, elikadura-iturri garrantzitsua dira itsaskiak (batez ere, molusku bibalbioak). Hala ere, kontsumitutako molusku gehienak kanpotik ekarritakoak dira; izan ere, eremu horretan, duela gutxi hasi da garatzen bibalbioen akuikultura. Hainbat arrazoi daude horretarako; hala nola, ibai eta estuario nagusiek dituzten uren kalitate-arazoak [31], kostaldeko baldintza hidrodinamiko latzak [32] eta itsas habitatentzako dauden babes- eta kontrol-erregulazio zorrotzak [33].

EAEko bibalbioen akuikulturarako eremu bakarra itsaso zabalean kokatuta dago, Mendexan (Ondarroa eta Lekeitio artean), kostaldetik $2 \mathrm{~km}$-ra (3. irudia). Eremu horretan, $45 \mathrm{~m}$ inguruko sakonera dago, eta muskuiluak (Mytilus galloprovincialis) hazten dira nagusiki [34, 35], «longline» sisteman kokatuak. Mendexako muskuiluen ekoizpen komertziala 2019an hasi zen. Akuikulturarako eremu hori itsas zabalean kokatzeak hainbat abantaila eskaintzen ditu kostaldeko eremuekin konparatuz gero; hala nola, kostaldean jatorria duten kutsadura-iturrietatik aldenduta egotea, uraren gazitasunaren egonkortasun handiagoa, azaleraren erabilera hobea, eta inpaktu bisual eta ekologiko txikiagoak [36].
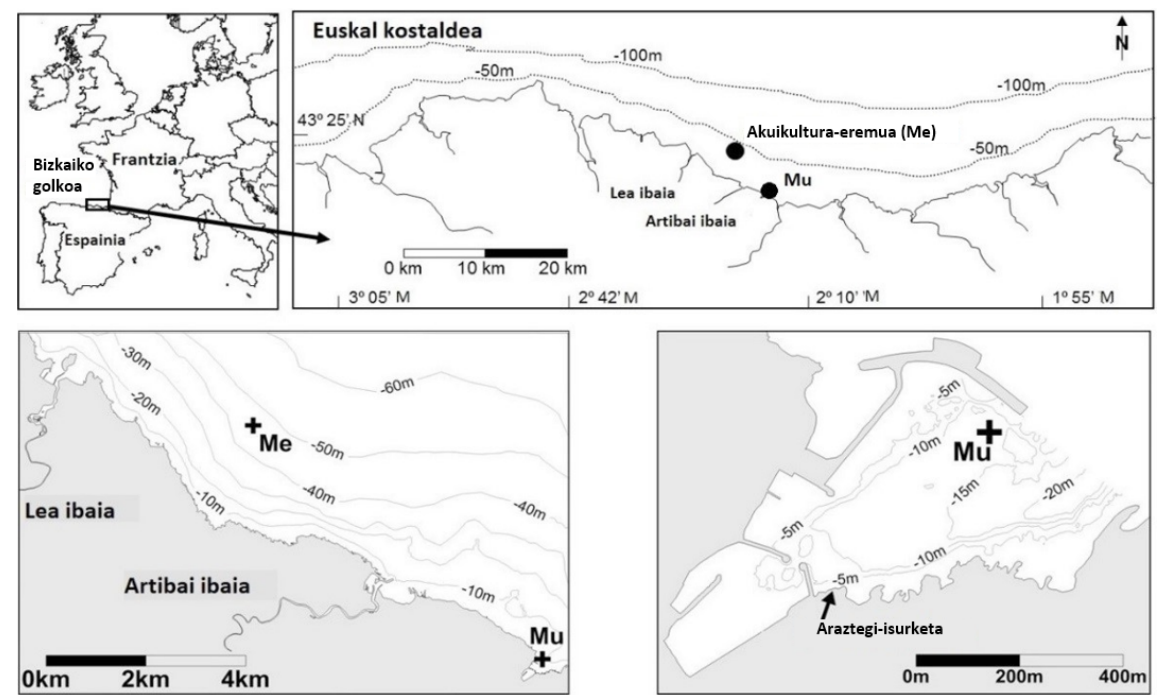

3. irudia. Euskal kostaldea eta akuikultura-eremuen kokalekuak. Mu: Mutriku; Me: Mendexa. Bilbao et al.etik moldatua [37]. 
Jone Bilbao, Oihane Muñiz, Marta Revilla, José Germán Rodríguez, Aitor Laza-Martínez, Sergio Seoane

Hala ere, akuikultura garatzeko, kostaldetik gertuago dauden beste kokaleku batzuen aukera ere eztabaidatu da; Mutrikuko portua, adibidez. 2016tik, bibalbioen hazkuntzarako plataforma esperimental bat dago $\mathrm{Mu}-$ trikuko portuaren kanpoaldean, eta, bertan, muskuiluak kaiola flotagarrietan hazten dira. Eremu hori Mendexatik 7,5 km-ra dago, batez besteko sakonera $15 \mathrm{~m}$ ingurukoa da, eta olatuen ekintzatik babestuta dago kai-mutur bati esker (3. irudia). Bertara urak isurtzen dituen ibairik egon ez arren, portuak inguruko herritarren (5.300 biztanle, gutxi gorabehera) hondakin-urak tratatzen dituen araztegi baten isurketa jasotzen du. Hala ere, Mutrikuko urzutabeak euskal kostaldeko urentzako aurretik deskribatutako baldintza tipikoak erakusten ditu [37], eta araztegiaren eragin nabarmenik ez da behatu.

\subsection{Fitoplanktonaren ikerketa EAEn}

Hainbat ikerketa gauzatu dira euskal kostaldeko fitoplankton-komunitateak ezagutzeko. Ikerketa hauetako gehienen helburua estuario eta itsaso zabaleko uretan dauden fitoplankton-komunitateen egitura taxonomikoa eta dinamikak deskribatzea izan da [2, 38-41]. Gainera, beste asko eremu horretako fitoplankton toxikoaren presentzia eta espezie horien taxonomia eta dinamikak ikertzean zentratu dira [42-48]. Hala ere, biotoxinen inguruko ikerketak oso urriak dira eskualde horretan, eta, orain arte, azaspirazido [49] eta pinnatoxinetan [50] bakarrik zentratu dira.

Bibalbioen akuikulturarekin erlazionatutako fitoplanktonaren ikerketak berriki hasi dira EAEko uretan. 2017an, Muñizek eta lankideek [51] EAEko kostaldeko 16 puntutan eta itsas zabaleko hiru puntutan 11 urtean zehar bildutako fitoplankton-komunitateen datuak aztertu zituzten, eskualde horrek akuikultura garatzeko zuen ahalmena ebaluatzeko aurretiazko urrats gisa. Gerora, ikerketa horiek eremu zehatzetara mugatu dira, eta, azken bi urteotan, Mendexako itsas zabaleko eremuak eta Mutrikuko portuak bibalbioen akuikultura garatzeko duten egokitasuna aztertu da $[35,37,52]$.

Mendexako eta Mutrikuko ikerketa horietan fitoplankton-komunitateen egitura aztertu zen Utermöl teknikaren [53] bidez. Mikroskopio bidezko teknika horrekin, hainbat osagairen zelula-kontzentrazioa (zelula/L) zenbatetsi eta, taxon bakoitzaren biobolumenean oinarrituz, osagaien biomasa $(\mu \mathrm{g} \mathrm{C} / \mathrm{L})$ ezagutu zen, eta baita tamainaren arabera ingestiorako eta erretentziorako aproposak ziren aztertu ere. Gainera, in situ neurtutako $a$ klorofila-balioak ere erabili ziren biomasa fitoplanktoniko totalaren balioespen gisa. Horrez gain, Bilbaok eta lankideek [37] taxon toxikoen presentzia eta ugaritasuna eta muskuiluen haragian aurkitutako toxina-kontzentrazioak aztertu zituzten Mendexan eta Mutrikun. Itsaskien bidezko intoxikazio-arriskua zehazteko, zelula-kontzentrazioen alerta-mailak aplikatu zitzaizkien ardura handiena sortzen duten sindromeen (ASP, PSP, DSP) eragileei. Horretarako erabili zi- 
ren muga-balioak [54] aurreko ikerketetan euskal itsasoko uretan erabili direnen artean murriztaileenak izan ziren [51]. Muskuiluetako toxina-edukiari dagokionez, Europar Batasunak arautzen dituen toxinen kontzentrazioa aztertu zen, legezko mugak gainditzen ziren zehazteko asmoz.

\section{MENDEXAKO ETA MUTRIKUKO FITOPLANKTON- KOMUNITATEAK}

\subsection{Fitoplanktonen ugaritasuna}

Mendexako eta Mutrikuko komunitate fitoplanktonikoen ugaritasuna aztertzeko erabilitako parametroei (zelula-kontzentrazioa, karbono-unitateetan emandako fitoplankton-biomasa eta $a$ klorofilaren kontzentrazioa) dagokienez [35, 52], bi eremuetan emaitza oso antzekoak lortu ziren.

Mendexako itsas zabaleko estazioan, zelula-kontzentrazioa 3,4 $\times 10^{4}$ eta $5,1 \times 10^{6}$ zelula/L bitartekoa izan zen, eta, Mutrikuko portuko estazioan $1,9 \times 10^{4}$ zelula/L eta $7,1 \times 10^{5}$ zelula/L bitartekoa; bi eremuetako zelulaugaritasun minimoak oso antzekoak izan ziren. Gainera, bi lekuetan erregistratutako batez besteko zelula-kontzentrazioak euskal kostaldean aurretik egindako ikerketetan [51] lortutako balioen barruan daude. Fitoplanktonbiomasari dagokionez, balio maximoetan ezberdintasun nabarmena ikusi zen Mendexa (435 $\mu \mathrm{g} \mathrm{C/L})$ eta Mutriku $(94,4 \mu \mathrm{g} \mathrm{C} / \mathrm{L})$ artean. Hala ere, pentsatu behar da emandako biomasa-datuak zelulen biobolumenean oinarritutako zeharkako balioespenak direla, eta horri lotutako errorea daramatela $[55,56]$. Biomasa/a klorofila erlazioak aldakortasuna erakuts badezake ere, ohikoagoa da $a$ klorofilaren balioa erabiltzea biomasa fitoplanktoniko totalaren balioespenerako. Horrela, $a$ klorofilaren kontzentrazioarekin, aukera handiagoa dago Mendexako eta Mutrikuko biomasa-balioak beste akuikultura-eremu batzuekin konparatzeko.

Mendexak eta Mutrikuk $a$ klorofila-balio baxuak erakutsi zituzten Muñizek eta lankideek [35] eta Bilbaok eta lankideek [52] egindako ikerketetan. Batetik, Mendexan $a$ klorofilaren batez besteko kontzentrazioa $0,6 \mu \mathrm{g} / \mathrm{L}$ izan zen; $6 \mu \mathrm{g} / \mathrm{L}$-ko maximoa martxoan lortu zen. Bestetik, Mutrikuko batez besteko $a$ klorofilaren kontzentrazioa $0,5 \mu \mathrm{g} / \mathrm{L}-\mathrm{koa}$ izan zen; $1,4 \mu \mathrm{g} / \mathrm{L}-k o$ maximora heldu zen otsailean. Bi eremuetan $1 \mu \mathrm{g} / \mathrm{L}-\mathrm{z}$ azpiko kontzentrazioak egon ziren gehienetan. Ikertzaile batzuen arabera [57, 58], muskuiluek elikatzeko iragazketa aktibatzeko behar duten gutxieneko $a$ klorofila kontzentrazioa $0,5 \mu \mathrm{g} / \mathrm{L}$ da. Atariko balio hori gainditu egin zen Mendexako laginen \% 62an eta Mutrikuko laginen \% 54an. Horrek Mendexa eta Mutriku antzeko bihurtzen ditu akuikultura garatzeko duten egokitasunari dagokionez, fitoplankton-biomasa totalari erreparatuz gero. 
Jone Bilbao, Oihane Muñiz, Marta Revilla, José Germán Rodríguez, Aitor Laza-Martínez, Sergio Seoane

Batez besteko $a$ klorofila balio baxu horiek ohikoak dira EAEko ur euhalinoetan, eta eremuaren baldintza oligotrofikoak islatzen dituzte. Euskal kostaldean aurretik egindako ikerketek [59] adierazi zutenez, gainazaleko uren $a$ klorofila-balio maximoak $2 \mu \mathrm{g} / \mathrm{L}$ eta $4 \mu \mathrm{g} / \mathrm{L}$ artekoak izan ohi dira. Europako beste akuikultura-eremu batzuekin alderatuta, Mendexako eta Mutrikuko biomasa-balioak, eta oro har euskal kostaldekoak, oso baxuak dira. Galiziako itsasadarretan egindako ikerketek - han izaten da Espainiako muskuiluen ekoizpen handiena $-0,7 \mu \mathrm{g} / \mathrm{L}$ (neguan) eta $13,6 \mu \mathrm{g} / \mathrm{L}$ (udaberrian) bitarteko $a$ klorofila-balioak erregistratu zituzten [29]; zenbaitetan, $20 \mu \mathrm{g} / \mathrm{L}$-ra ere heldu ziren [60]. Spyrakos-ek eta lankideek [61] ere Mendexan eta Mutrikun aurkitutako $a$ klorofila-kontzentrazioak baino altuagoak lortu zituzten Rias Baixasen: $1 \mu \mathrm{g} / \mathrm{L}-\mathrm{z}$ azpikoak neguan, $5 \mu \mathrm{g} / \mathrm{L}$ ingurukoak udan eta $8 \mu \mathrm{g} / \mathrm{L}-\mathrm{ra}$ artekoak udaberri eta udazkenean. Europako beste akuikultura-eremu ezagunetan egindako ikerketek, Mantxako kanaleko ekialdean (Frantzian) egindakoek adibidez, berresten dute Mendexako eta Mutrikuko $a$ klorofila-balioak baxuak direla, 1 eta $25 \mu \mathrm{g} / \mathrm{L}$ bitarteko [62] edo 0,9 eta $18,9 \mu \mathrm{g} / \mathrm{L}$ bitarteko kontzentrazioak [63] aurkitu baitira bertan.

Argitu behar da uretan momentu konkretu batean neurtutako fitoplankton-biomasak ez duela zuzenean maila trofiko altuagoek asimila dezaketen kopururik adierazten. Horren neurri zehatzagoa ekoizpen primarioarena da. Ezagutzen diren Bizkaiko golkoko hegoaldeko gainazaleko uren ekoizpen primarioaren balioak nahiko baxuak dira Europako beste eremu batzuekin konparatuz, bereziki euskal kostaldekoak [64, 65]. Hori bat dator, ez bakarrik Mendexan eta Mutrikun baizik eta, euskal kostalde osoan zehar aurkitutako $a$ klorofila-balio baxuekin [66]. Gainera, $a$ klorofila-kontzentrazioekin bezala, EAEko uretan erregistratutako ekoizpen primarioaren balio altuenak askoz txikiagoak dira Galiziako itsasadarretan aurkitutako maximoak baino [67].

\subsection{Fitoplankton-komunitatearen osaketa}

Eremu bateko fitoplankton-biomasa totalaren kontzentrazioa bibalbioen hazkuntzarako faktore garrantzitsua izan arren, landa-azterketetan ikusi izan dan bibalbioen hazkuntza-tasak fitoplanktoneko osagai zehatzen ugaritasunarekin erlazionatuta zeudela, komunitateko biomasa totalarekin baino gehiago [68].

Azken ikerketen arabera [35, 52], Mendexako eta Mutrikuko fitoplankton-komunitateak haptofitoz, kriptofitoz, diatomeoz eta dinoflagelatuz osatuta zeuden nagusiki, eta azken horien presentzia handiagoa izan zen itsas zabaleko eremuan. Gainera, aipatzekoa da alga berdeen (klorofitak eta euglenofitak) presentzia ere, batez ere Mutrikun. Orokorrean, haptofitoak izan ziren bi eremuetako talderik ugariena zelula-kontzentrazioari dagokionez; hala ere, beste talde batzuek ere ekarpen nabarmena egin zioten komu- 
nitatearen kontzentrazio totalari. Mendexan, aipagarria da dinoflagelatuek eta diatomeoek izandako garrantzia; Mutrikun, berriz, kriptofito eta diatomeoena. Gainera, fitoplankton talde bakoitzaren kontzentrazioa aldatuz joan zen urteko sasoiaren arabera (4. irudia), eta, horrekin batera, baita bakoitzak fitoplankton-kontzentrazio totalari egiten zion ekarpena ere. Ikusitako joerak berdinak izan ziren bi ikerketa-eremuetan: diatomeoen ugaritasun maximoa neguan izan zen, dinoflagelatu eta kriptofitoena udazkenean, eta haptofitoena udaberri eta uda artean.

Zelula ugaritasuna

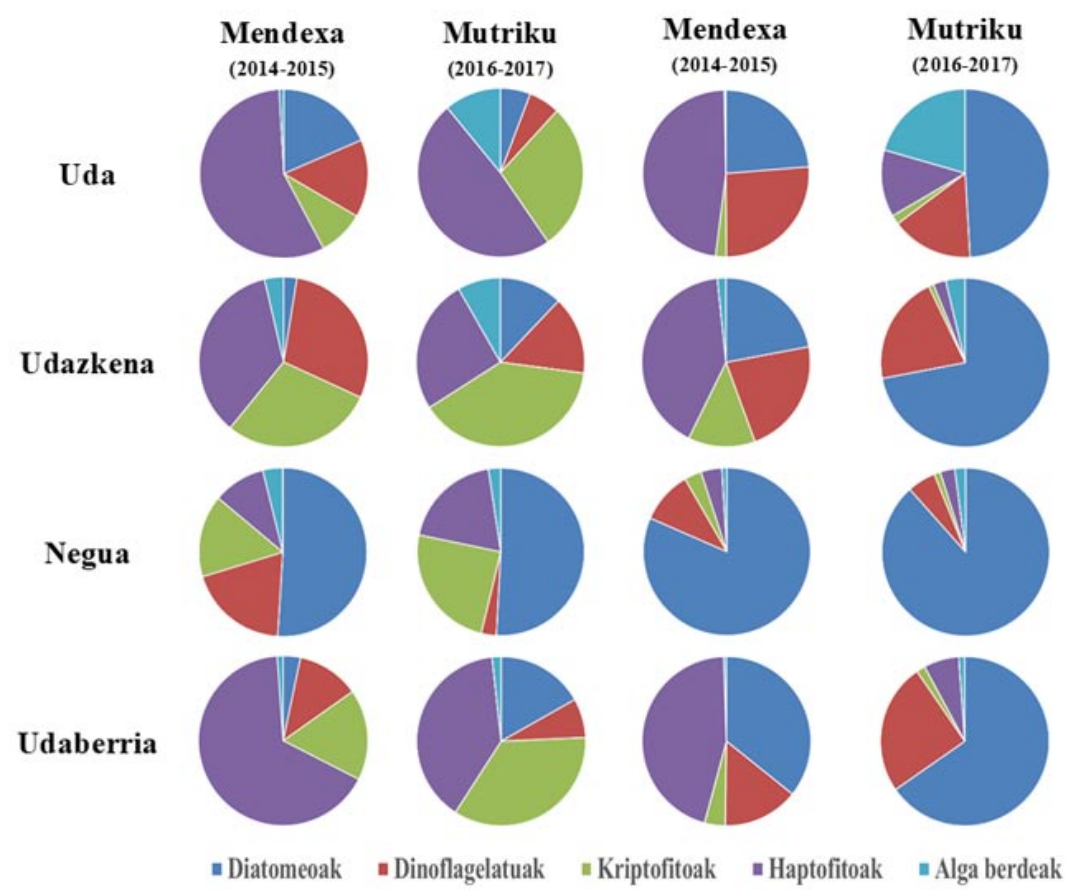

4. irudia. Fitoplankton talde nagusiek ikerketa-eremuetako zelula-ugaritasunari eta biomasari urtaro bakoitzean egiten dioten ekarpena, gainazaleko ure$\tan [35,52]$.

Bestalde, Mendexan eta Mutrikun aurkitutako fitoplankton talde ugarienek eremu horietako biomasa totalari egiten zioten ekarpena aztertzerakoan, ikusi zen ekarpen handiena egiten zuen taldea ez zela beti zelula-kontzentrazio altueneko taldea [35, 52]. Mendexan, biomasak zelula-ugaritasunaren dinamika berdina jarraitu zuen: diatomeoen biomasa neguan gailendu zen, eta, gaine- 
Jone Bilbao, Oihane Muñiz, Marta Revilla, José Germán Rodríguez, Aitor Laza-Martínez, Sergio Seoane

rako urtaroetan, haptofitoek egin zuten ekarpen handiena. Bestalde, dinoflagelatuen ekarpena nabarmena izan zen udan eta udazkenean. Mutrikun, ordea, diatomeoak izan ziren urte osoan zehar biomasa totalari ekarpen handiena egin zion taldea; \% 52 eta \% 79 bitarteko batez besteko ekarpena, hain zuzen ere. Gainera, aipatzekoa da dinoflagelatuek biomasa totalari egindako ekarpena ere (\% 8-23), nahiz eta haien zelula-ugaritasuna ez zen oso handia izan.

Horrenbestez, ikusi da haptofitoak eta diatomeoak direla Mendexako eta Mutrikuko fitoplankton-komunitateetako osagai nagusiak, dinoflagelatuen noizbehinkako ekarpen garrantzitsuak ahaztu gabe. Horrek adierazten du, alde kualitatibotik, ona dela bi eremuetako komunitateek bibalbioen akuikultura gauzatzeko duten kalitate nutrizionala. Diatomeoak aberatsak dira azido eikosapentanoikoan (EPA), eta haptofitoak azido dekosahexanoikoaren (DHA) iturri garrantzitsua [69]. EPA eta DHA bibalbioek behar dituzten gantz azido esentzialetako bi dira; lehenengoak funtzio energetikoa du [70, 71], eta bigarrenak hazkundea sustatzen du [72]. Hori dela eta, Isochrysis galbana eta Pavlova lutheri bezalako espezieak elikagai gisa oso erabiliak dira moluskuen akuikulturan, eta ohikoa da espezie horiez eta diatomeoz osatutako mikroalga-dieta mistoak erabiltzea bibalbio-haztegie$\tan [69,73-75]$. Dinoflagelatuei dagokienez, bibalbioen hazkuntzarako garrantzitsuak diren gantz azidoak dituzte, DHA konkretuki [34]. Gainera, muskuiluen elikaduraren inguruan egindako ikerketek [76] aurkitu dute dinoflagelatuak eta diatomeoak direla, gainerako fitoplankton taldeekin konparatuz, muskuiluengan erretentzio-tasa altuenak erakusten dituzten taldeak.

Horrez gain, deskribatutako fitoplankton-komunitatearen osaketa kontuan izanda, 2-20 $\mu \mathrm{m}$ bitarteko tamaina duten zelulen nagusitasun argia ikusi zen (\% 90 inguru), bai Mutrikun [52] baita Mendexan [51] ere. Hortaz, 4-45 $\mu \mathrm{m}$-ko zelula-tamaina egokitzat hartzen dela jakinda [4], Mendexako eta Mutrikuko fitoplankton-komunitateak onuragarriak dira muskuiluen hazkuntzarako, baita zelulen tamainaren araberako muskuiluen ingestio- eta erretentzio-eraginkortasunari dagokionez ere. Hala ere, esan beharra dago zelula-tarte horretan sartzen ziren taxon asko kateak eratzen dituzten diatomeoak zirela, eta, horrenbestez, tamaina handiagoko $(>20 \mu \mathrm{m})$ taxontzat hartu beharko liratekeela.

\subsection{Fitoplaktonak toxikotasun-arazoak eragin ditzake?}

Bilbaok eta lankideek [37], Mendexan eta Mutrikun 2016 eta 2017 urteen artean egindako ikerketan, potentzialki toxikoak diren 15 taxon identifikatu zituzten; aurretik ere deskribatu izan ziren taxon horiek Bizkaiko golkoko hego-ekialdean egindako ikerketetan [2, 35, 43, 45, 46, 48] (5. irudia). Mutrikun, Pseudo-nitzschia spp. diatomeo toxikoa aurkitu zen; dinoflagelatuak, ordea, 12 izan ziren: Alexandrium spp., cf. Azadinium spp., Dinophysis spp., Dinophysis acuminata, Goniaulax cf. spinifera, Gymno- 
diniales (Karlodinium-like), Ostreopsis cf. siamensis, Phalacroma spp. eta Takayama sp.. Beste fitoplankton taldeetatik taxon bakarra aurkitu zen, Phaeocystis globosa haptofitoa. Mendexan, potentzialki toxikoak ziren 15 taxon identifikatu ziren: Mutrikun aurkitutako berdinak gehi $c f$. Pseudochattonella sp., diktiokofizeoa.

Itsaskien akuikulturan toxikotasun-arriskurako ezarritako kontzentrazio-mugei dagokienez, Pseudo-nitzschia spp., Alexandrium spp. eta Dinophysis spp. taxonek arrisku-mugaz gaineko zelula-kontzentrazioak erregistratu zituzten Mendexan eta Mutrikun [37], \% 23ko eta \% 12ko maiztasunez, hurrenez hurren. Muskuiluen haragian egindako toxinen analisiari erreparatuz, Mendexan egindako laginketen \% 85an gainditu ziren kuantifikazio-mailak; Mutrikun, berriz, \% 40an [37]. Hala ere, azido okadaikoa (OA), DSParen eragilea dena, izan zen ikerketa guztian zehar araututako muga-kontzentrazioa gainditu zuen toxina bakarra.
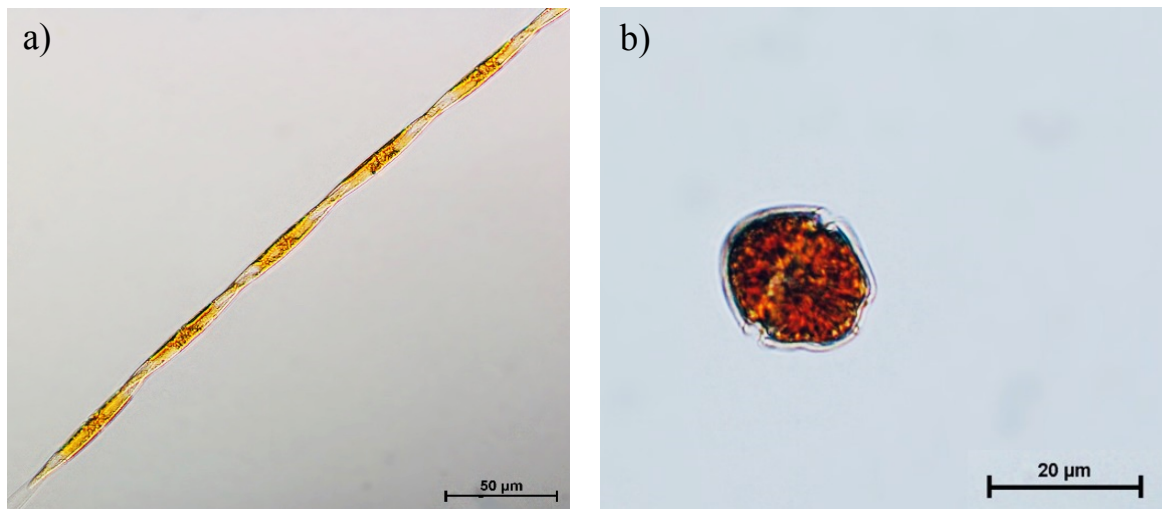

c)

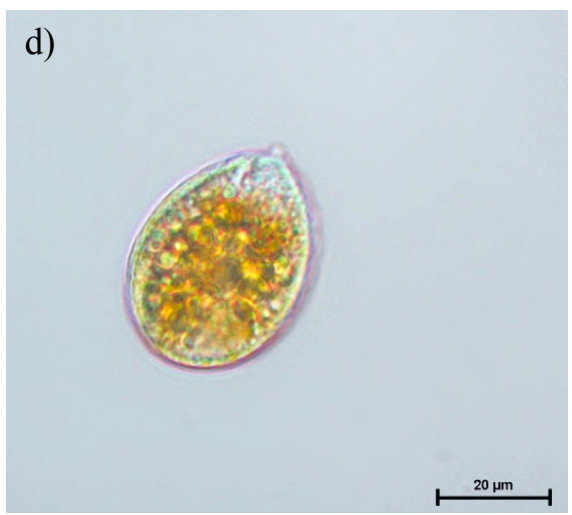

5. irudia. Mendexan eta Mutrikun aurkitutako taxon toxiko azpimarragarrienak: a) Pseudo-nitzschia spp.; b) Alexandrium spp.; c) Dinophysis acuminata; d) Ostreopsis siamensis. 
Jone Bilbao, Oihane Muñiz, Marta Revilla, José Germán Rodríguez, Aitor Laza-Martínez, Sergio Seoane

Pseudo-nitzschia spp. izan zen Mendexan eta Mutrikun aurkitutako taxon toxiko ugariena [37]. Genero horren alerta-muga (50 000 zelula/L) [54] hirutan gainditu zen bi eremuetan; hala ere, azido domoikoa (ASParen eragilea) behin bakarrik aurkitu zen muskuiluen haragian, eta bere kontzentrazioak ez zuen muga legala gainditu. Horren arrazoi nagusia izan daiteke zenbatutako Pseudo-nitzschia generoko zelulen artean azido domoikoa ekoizten ez zuten espezieak ere zenbatu zirela; izan ere, Utermöhl teknikaren bidez genero horretako espezie gutxi identifika daitezke, eta zenbaketak genero-mailan geratzen dira askotan. Anduien isolamenduan eta beren ADN eta elektroi-mikroskopia bidezko analisietan oinarrituz, genero horretako 12 espezie deskribatu ziren Bilboko Abrako uretan [43, 44]. Utermöhl teknikaren bidez identifikagarri direnen artean, euskal kostaldeko uretan toxikoak diren $P$. australis, $P$. galaxiae edo $P$. multistriata espezieak behatu ziren $[2,51]$. Azido domoikoa 2016 eta 2017 artean behin bakarrik detektatu bazen ere, Europa osoko itsaskietan aurkitu da, bereziki Erresuma Batuan, Irlandan eta Frantzian [77], eta urtero akuikultura-eremuen itxierak eragin ditu.

Alexandrium spp. dinoflagelatuen kasuan, haien presentzia hutsak intoxikazio-arriskua eragiten du, gizakien osasunerako oso arriskutsuak diren saxitoxinak (PSParen eragileak) ekoizteko duten gaitasunaren erruz. Hori kontuan hartuz, arrisku-egoerak lau aldiz detektatu ziren Mendexan eta behin Mutrikun, 2016 eta 2017 arteko zikloan; muskuiluen haragian aurkitutako saxitoxinen kontzentrazioa, ordea, araututako mugaren azpitik egon zen beti [37], ziurrenik, Alexandrium spp. taxonaren zelula-kontzentrazioa oso baxua izan zelako (40 zelula/L-ko maximoa). Gainera, Pseudo-nitzschia spp. taxonarekin bezala, Uthermöl teknikarekin Alexandrium generoko zelulak ez direnez espezie-mailara arte identifikatzen, ezin dira bereizi genero horren espezie toxikoak eta kaltegabeak, eta horrek zaildu egiten du beren monitorizazioa. Aurretik deskribatu izan dira genero horrek euskal uretan duen agerpen-maiztasuna eta ugaritasun urriak [2]. Hala ere, ezagutzen diren genero horren 34 espezieetatik 14 gai dira PSP toxinak ekoizteko [78], eta, beraz, behatutako agerpenak urriak izanda ere, kontuan hartzekoa da muskuiluetan aurkitutako saxitoxina-kontzentrazioa, PSPa fitoplankton toxikoarekin lotutako intoxikazio-sindromerik hedatu eta larriena delako [23].

Dinophysis generoari dagokionez, toxikotasun-arriskurako ezarritako zelula-ugaritasunaren muga (100 zelula/L) [54] behin gainditu zen ikerketa-eremu bakoitzean aipatutako epean [37]. Gainera, genero horretako zenbait espeziek ekoizten duten azido okadaikoak (DSParen eragilea) araututako mugakontzentrazioa gainditu zuen (hiru aldiz) Mendexako eta (behin) Mutrikuko muskuiluetan. Gainera, Bilbaok eta lankideek [37] ikusi zuten Dinophysis generoaren eta muskuiluetan aurkitutako azido okadaikoaren kontzentrazioa handiagoa zela Mendexako akuikultura-eremuan, eta toxikotasun-arriskua handiagoa dela itsas zabaleko eremuan. Aipatutako generoak eta horiek ekoizten dituzten toxinak dira bibalbioen akuikulturak pairatzen dituen arrisku nagusiak [79]. 
Arreta berezia eskaini behar zaio Dinophysis acuminata espezieari. Mendexan eta Mutrikun agertzen den espezie hori, orokorrean, kontzentrazio baxuetan $(<100$ zelula/L) agertzen da euskal kostaldean, baina kontzentrazio altuak ere $\left(5 \times 10^{3}\right.$ zelula/L-ko maximoak $)$ aurkitu izan dira eremu horretako zonalde euhalinoetan [47]. Horrez gain, Frantziako mendebaldeko kostaldeko ostra eta muskuiluetan aurkitu den azido okadaikoaren kontzentrazio altuen eragile nagusia da $[48,80]$. Gainera, D. acuminata Iberiar penintsulako ipar-mendebaldean gehien agertzen den taxon toxikoetako bat da [79]. Are gehiago, Galiziako itsasadar eta kostaldeetako akuikultura-eremuek itxiera luzeak eta kalte sozioekonomiko latzak pairatzen dituzte D. acuminata eta D. acuta taxonen ondorioz [81]. Horrek, aldi berean, Galiziako moluskuak kutsatzen dituen toxina nagusia azido okadaikoa izatea azaltzen du [82, 83]. Halaber, Galizian, azido okadaikoaren (eta, orokorrean, toxina lipofilikoen) ondoriozko akuikultura-jardueren itxiera gehienak udaberria eta udazkena bitartean izaten dira; hain zuzen, udaberria izaten da sasoirik txarrena [84]. Galizian udaberrian izaten den toxina lipofilikoen gorakada hori bat dator Mutrikun eta Mendexan ikusi denarekin; izan ere, Bilbaok eta lankideek [37] udaberrian bakarrik aurkitu zituzten azido okadaikoaren mugaz gaindiko kontzentrazioak.

Mutrikun Dinophysis spp. taxonaren eta azido okadaikoaren kontzentrazio baxuagoak aurkitu ziren arren, beste arrisku potentzial batzuk izan dira bertan; hala nola, Ostreopsis spp. bezalako dinoflagelatu bentoniko toxikoaren presentzia handiagoa. Azken urteotan Mediterraneoan eta Zeelanda Berrian izandako Ostreopsis spp. taxonaren loraldiek arriskuan jarri dute itsaski-kontsumoaren segurtasuna, dinoflagelatu horiek ekoizten dituzten palitoxina analogoen ondorioz [85]. Mutrikun aurkitutako kontzentrazioak Italiako Osasun Ministerioak [86] ezarritako Ingurumen Alarma balioen $\left(10^{4}\right.$ zelula/L) azpitik egon arren, ezin da baztertu Ostreopsis spp. euskal kostaldeko gune babestuetan ugaritzeko aukera [45]. Mutrikun, eta orokorrean kostaldeko eremuetan, organismo bentonikoen ugaritasun handiagoa egotea zuzenki erlazionatuta dago sakonerarekin; izan ere, sakonera txikiko eremuetan aukera daukate hondoan egon eta argia eskuragarri izateko. Horrenbestez, Mutriku bezalako eremuetan akuikultura garatzekotan, kontuan hartzekoa da Ostreopsis generoak izan dezakeen arriskua, oraindik euskal kostaldeko akuikulturarako kaltegarria ez den arren.

Azkenik, aipagarria da toxinen presentziak muskuiluen fisiologia eta biziraupenerako ekar dezakeen arriskua. Nahiz eta toxinen efektua iragankorra izan, hainbat ikerketetan frogatu da toxinek eragin negatiboak dituztela muskuiluen metabolismoan eta funtzio neuronalean, baita kuskuen itxiera, elikadura, bihotz-jarduera eta arnasketa bezalako jokabidefuntzioetan ere [87-91]. Gainera, toxina mota batzuek ugalketa- eta hazkunde-tasak murriztu ditzakete itsas bibalbioetan, populazio naturalen heriotza eraginez $[92,93]$. 
Jone Bilbao, Oihane Muñiz, Marta Revilla, José Germán Rodríguez, Aitor Laza-Martínez, Sergio Seoane

\section{ONDORIOA}

Azken urteetan, Mendexan eta Mutrikun egindako ikerketei esker jakin da bi eremu horietako fitoplankton-komunitateak, alde kualitatibotik, bibalbioen akuikulturarako aproposak direla, diatomeo, haptofito eta dinoflagelatuek duten garrantziari eta zelulen tamaina egokiari esker. Hala ere, zenbait oztopo ere aurkitu dira; hala nola, eremu horietako $a$ klorofila-balio baxuak - beste akuikultura-eremu batzuekin (Galizia, adibidez) alderatuz- edo potentzialki toxikoak diren espezieen agerpena. Mendexan eta Mutrikun potentzialki toxikoak diren taxonen eta haien toxinen presentzia aurkitu da, eta, askotan gertatu ez zen arren, hainbat aldiz gainditu dira itsaskien toxikotasun-arriskua adierazten duten zelula eta toxinen kontzentrazio-mugak. Horrenbestez, argi geratu da ezinbestekoa dela euskal kostaldean potentzialki toxikoak diren fitoplankton-espezieen jarraipena egitea bibalbioen akuikultura era eraginkorrean garatu ahal izateko. Konkretuki, arreta berezia eskaini beharko zaio D. acuminata espezieari, Mendexan batez ere, espezie horrek beste akuikultura-eremuetan eragiten dituen arazoengatik. Gainera, PSParen eragile diren Alexandrium generoko espezieen ikerketan sakondu beharko litzateke Euskal Autonomia Erkidegoko uretan, informazio falta dagoelako oraindik haien presentziaren inguruan.

\section{ESKER ONAK}

Artikulu hau UPV/EHUk finantzatutako «Itsasoko eta estuarioko planktonaren ekologia» ikerketa-taldeak (GIU19/059) jasotako laguntzari eta doktorego aurreko bekari (J.B.) (UPV/EHU-PIF 18/306) esker eta Eusko Jaurlaritzak (Ekonomiaren Garapena, Jasangarritasuna eta Ingurumen Saila) finantzatutako «Mejora en los protocolos biosanitarios para la comercialización de la producción de moluscos» proiektuari (00002-INA2019-33) esker idatzi da.

\section{BIBLIOGRAFIA}

[1] HELM, M. M., BOURNE, N. eta LOVATELLI, A. 2004. Hatchery Culture of Bivalves: A Practical Manual, 2004. Food and Agriculture Organization of the United Nations, FAO Fisheries Department, Roma, Italia.

[2] MUÑIZ, O., RODRÍGUEZ, J., REVILLA, M., LAZA-MARTÍNEZ, A., SEOANE, S. eta FRANCO, J. 2018. «Seasonal variations of phytoplankton community in relation to environmental factors in an oligotrophic area of the European Atlantic coast (southeastern Bay of Biscay)». Regional Studies in Marine Science, 17, 59-72.

[3] STROHMEIER, T., STRAND, Ø., ALUNNO-BRUSCIA, M., DUINKER, A. eta CRANFORD, P.J. 2012. "Variability in particle retention efficiency 
by the mussel Mytilus edulis». Journal of Experimental Marine Biology and Ecology, 412, 96-102.

[4] CRANFORD, P., DUARTE, P., ROBINSON, S., FERNÁNDEZ-REIRIZ, M., eta LABARTA, U. 2014. «Suspended particulate matter depletion and flow modification inside mussel (Mytilus galloprovincialis) culture rafts in the Ría de Betanzos, Spain». Journal Of Experimental Marine Biology And Ecology, 452, 70-81.

[5] LUCAS, M., NEWELL, R., SHUMWAY, S., SEIDERER, L. eta BALLY, R. 1987. Particle clearance and yield in relation to bacterioplankton and suspended particulate availability in estuarine and open coast populations of the mussel Mytilus edulis. Marine Ecology Progress Series, 36, 215-224.

[6] STENTON-DOZEY, J., eta BROWN, A. 1992. «Clearance and retention efficiency of natural suspended particles by the rock-pool bivalve Venerupis corrugatus in relation to tidal availability». Marine Ecology Progress Series, 82, 175-186.

[7] MØHLENBERG, F.eta RIISGÅRD, H.U., 1978. «Efficiency of particle retention in 13 species of suspension feeding bivalves». Ophelia, 17, 239-246.

[8] RIISGARD, H.U., 1988. «Efficiency of particle retention and filtration rate in 6 species of Northeast American bivalves». Marine Ecology Progress Series, 45, 217-223.

[9] JØRGENSEN, C.B., 1990. «Functional morphology of bivalve feeding». Non: JØRGENSEN, C.B. (Ed.), Bivalve Filter Feeding: Hydrodynamics, Bioenergetics, Physiology and Ecology. Olsen \& Olsen, Fredensborg, 4-10.

[10] MARSHALL, R., MCKINLEY, S., eta PEARCE, C. 2010. «Effects of nutrition on larval growth and survival in bivalves». Aquaculture, 2, 33-55.

[11] PETTERSEN, A.K., TURCHINI, G.M., JAHANGARD, S., INGRAM, B.A. eta SHER-MAN, C.D. 2010. «Effects of different dietary microalgae on survival, growth, settlement and fatty acid composition of blue mussel (Mytilus galloprovincialis) larvae». Aquaculture, 309, 115-124.

[12] GALlEY, T.H., BATISTA, F.M., BRAITHWAITE, R., KING, J. eta BEAUMONT, A.R. 2009. «Optimisation of larval culture of the mussel Mytilus edulis (L.) ». Aquaculture International, 18, 315-325.

[13] MARTINEZ-FERNANDEZ, E. eta SOUTHGATE, P.C. 2007. «Use of tropical microalgae as food for larvae of the black-lip pearl oyster Pinctada margaritifera». Aquaculture, 263, 220-226.

[14] STROMGREN, T. eta CARY, C. 1984. "Growth in length of Mytilus edulis $\mathrm{L}$ fed on different algal diets». Journal of Experimental Marine Biology and Ecology, 76, 23-34.

[15] GRANÉLI, E. eta TURNER, J. 2008. Ecology of harmful algae. Springer, Berlin.

[16] LAWRENCE, J., LOREAL, H., TOYOFUKU, H., HESS, P., KARUNASAGAR, I. eta ABABOUCH, L. 2011. Assessment and management of biotoxin risks in bivalve molluscs. FAO Fisheries and Aquaculture Technical Paper, Rome, 551, 337. 
Jone Bilbao, Oihane Muñiz, Marta Revilla, José Germán Rodríguez, Aitor Laza-Martínez, Sergio Seoane

[17] ANDERSON, D. 2009. «Approaches to monitoring, control and management of harmful algal blooms (HABs)». Ocean \& Coastal Management, 52, 342-347.

[18] DAVIDSON, K. eta BRESNAN, E. 2009. «Shellfish toxicity in UK waters: a threat to human health? ». Environmental Health, 8, S12.

[19] CAO, R., WANG, D., WEI, Q., WANG, Q., YANG, D. eta LIU, H. 2018. «Integrative Biomarker Assessment of the Influence of Saxitoxin on Marine Bivalves: A Comparative Study of the Two Bivalve Species Oysters, Crassostrea gigas, and Scallops, Chlamys farreri». Frontiers in Physiology, 9, 1173.

[20] HEISLER, J., GLIBERT, P., BURKHOLDER, J., ANDERSON, D., COCHLAN, W., DENNISON, W., DORTCH, Q., GOBLER, C., HEIL, C., HUMPHRIES, E., LEWITUS, A., MAGNIEN, R., MARSHALL, H., SELLNER, K., STOCKWELL, D., STOECKER, D. eta SUDDLESON, M. 2008. «Eutrophication and harmful algal blooms: A scientific consensus». Harmful Algae, 8, 3-13.

[21] DAVIDSON, K., GOWEN, R.J., HARRISON, P.J., FLEMING, L.E., HOAGLAND, P. eta MOSCHONAS, G. 2014. «Anthropogenic nutrients and harmful algae in coastal waters». Journal of Environmental Management, 146, 206-216.

[22] GLIBERT, P., ANDERSON, D., GENTIEN, P., GRANÉLi, E. eta SELLNER, K. G. 2005. «The global, complex phenomena of harmful algal blooms». Oceanography, 18, 137-147.

[23] HALLEGRAEFF, G., ANDERSON, D., CEMBELLA, A. eta ENEVOLDSEN, H. 2004. Manual on harmful marine microalgae. UNESCO, Paris.

[24] FAO. 2017. FAO yearbook. Fishery and Aquaculture Statistics 2015. FAO, Roma, Italia. Eskuragarri: http://www.fao.org/3/a-i7989t.pdf

[25] FAO. 2018. FAO anuario. Estadísticas de pesca y acuicultura 2016. Roma, Italia. Eskuragarri: http://www.fao.org/fishery/static/Yearbook/YB2016_USBcard/root/aquaculture/b54.pdf.

[26] DE LA FIGUERA, R. 2017. «Visión general del sector acuícola nacional - España 2005-2018». Departamento de Pesca y Acuicultura de la FAO. 2017ko maiatzaren 12an eguneratua. Eskuragarri: http://www.fao.org/fishery/countrysector/naso_spain/es

[27] EUROFISH. 2016. Overview of the Spanish fisheries and aquaculture sector. Eskuragarri: https://www.eurofish.dk/spain

[28] FIGUEIRAS, F., LABARTA, U. eta REIRIZ, M.F. 2002. «Coastal upwelling, primary production and mussel growth in the Rías Baixas of Galicia». Hydrobiologia, 484, 121-131.

[29] VARELA, M., PREGO, R., PAZOS, Y. eta MOROÑO, Á. 2005. «Influence of up- welling and river runoff interaction on phytoplankton assemblages in a Middle Galician Ria and Comparison with northern and southern rias (NW Iberian Peninsula)». Estuarine and Coastal Shelf Science, 64, 721-737.

[30] APROMAR (Asociación Empresarial de Acuicultura de España). 2018. La Aquicultura en España. 
[31] CHUST, G., BORJA, A., LIRIA, P., GALPARSORO, I., MARCOS, M., CABALLERO, A. eta CASTRO, R. 2009. «Human impacts overwhelm the effects of sea-level rise on Basque coastal habitats (N Spain) between 1954 and 2004». Estuarine, Coastal and Shelf Science, 84, 453-462.

[32] GALPARSORO, I., LIRIA, P., LEGORBURU, I., BALD, J., CHUST, G., RUIZ-MINGUELA, P., PÉREZ, G., MARQUÉS, J., TORRE-ENCISO, Y., GONZÁLEZ, M. eta BORJA, Á. 2012. «A Marine Spatial Planning Approach to Select Suitable Areas for Installing Wave Energy Converters (WECs), on the Basque Continental Shelf (Bay of Biscay) ». Coastal Management, 40, 1-19.

[33] PASCUAL, M., BORJA, A., EEDE, S., DENEUDT, K., VINCX, M., GALPARSORO, I. eta LEGORBURU, I. 2011. «Marine biological valuation mapping of the Basque continental shelf (Bay of Biscay), within the context of marine spatial planning». Estuarine, Coastal and Shelf Science, 95, 186-198.

[34] AZPEITIA, K., FERRER, L., REVILLA, M., PAGALDAI, J. eta MENDIOLA, D. 2016. «Growth, biochemical profile, and fatty acid composition of mussel (Mytilus galloprovincialis Lmk.) cultured in the open ocean of the Bay of Biscay (northern Spain) ». Aquaculture, 454, 95-108.

[35] MUÑIZ, O., REVILLA, M., RODRÍGUEZ, J., LAZA-MARTÍNEZ, A. eta FONTÁN, A. 2019. «Annual cycle of phytoplankton community through the water column: Study applied to the implementation of bivalve offshore aquaculture in the southeastern Bay of Biscay». Oceanologia, 61, 114-130.

[36] MIZUTA, D.D., DIXON, M.S., MANEY, JR., E.J., FREGEAU, M. eta WIKFORS, G.H. 2019. «Offshore mussel aquaculture: strategies for farming in the changing environment of the Northeast U.S. shelf EEZ». Bulletin of Japan Fisheries Research and Education Agency, 49, 111-119.

[37] BILBAO, J., MUÑIZ, O., REVILLA, M., RODRÍGUEZ, J.G., LAZAMARTÍNEZ, A. eta SEOANE, S. 2020. «Suitability of two areas of the Basque coast to sustain shellfish aquaculture according to both the presence of potentially toxic phytoplankton and the biotoxins regulated by the European Union». Regional Studies in Marine Science, 36, 101279.

[38] TRIGUEROS, J.M. eta ORIVE, E. 2000. «Tidally driven distribution of phytoplankton blooms in a shallow, macrotidal estuary». Journal of Plankton Research, 22, 969-986.

[39] SEOANE, S., LAZA, A., URRUTXURTU, I. eta ORIVE, E. 2005. «Phytoplankton assemblages and their dominant pigments in the Nervión River Estuary». Hydrobiologia, 549, 1-13.

[40] SEOANE, S., LAZA, A. eta ORIVE, E. 2006. «Monitoring phytoplankton assemblages in estuarine waters: the application of pigment analysis and microscopy to size-fractionated samples». Estuarine and Coastal Shelf Science, 67, 343-354.

[41] GARMENDIA, M., REVILLA, M., BALD, J., FRANCO, J., LAZA-MARTÍNEZ, A., ORIVE, E., SEOANE, S., VALENCIA, V. eta BORJA, Á. 2011. «Phytoplankton communities and biomass size structure (fractionated chlo- 
Jone Bilbao, Oihane Muñiz, Marta Revilla, José Germán Rodríguez, Aitor Laza-Martínez, Sergio Seoane

rophyll " $a$ "), along trophic gradients of the Basque coast (northern Spain)». Biogeochemistry, 106, 243-263.

[42] ORIVE, E., LAZA-MARTINEZ, A. eta SEOANE, S. 2008. «Seguimiento del fitoplancton en el estuario del río Nervión: identificación de especies potencialmente tóxicas». Avances y tendencias en fitoplancton tóxico y biotoxinas, Actas de la IX Reunión Ibérica sobre Fitoplancton Tóxico y Biotoxinas, Cartagena, 7-10 Maitza 2007. Universidad Politécnica de Cartagena, 99-102.

[43] ORIVE, E., LAZA-MARTINEZ, A., SEOANE, S., ALONSO, A., ANDRADE, R. eta MIGUEL, I. 2010. «Diversity of Pseudo-nitzschia in the southeastern Bay of Biscay». Diatom Research, 25, 125-145.

[44] ORIVE, E., PÉREZ-AICUA, L., DAVID, H., GARCÍA-ETXEBARRIA, K., LAZA-MARTÍNEZ, A., SEOANE, S. eta MIGUEL, I. 2013. «The genus Pseudo-nitzschia (Bacillariophyceae) in a temperate estuary with description of two new species: Pseudonitzschia plurisecta sp. nov. and Pseudo-nitzschia abrensis sp. nov.». Journal of Phycology, 49, 1192-1206.

[45] LAZA-MARTINEZ, A., ORIVE, E. eta MIGUEL, I. 2011. «Morphological and genetic characterization of benthic dinoflagellates of the genera Coolia, Ostreopsis and Prorocentrum from the south-eastern Bay of Biscay». European Journal of Phycology, 46, 45-65.

[46] SEOANE, S., PUENTE, A., GUINDA, X. eta JUANES, J. 2012. «Bloom forming and toxic phytoplankton in transitional and coastal waters of Cantabria region coast (Southeastern Bay of Biscay, Spain)». Marine Pollution Bulletin, 64, 2860-2866.

[47] SEOANE, S. eta ORIVE, E. 2012. «First report of Dinophysis acuminata bloom in Basque waters, Northern Spain». Harmful Algae News, 46, 9.

[48] BATIFOULIER, F., LAZURE, P., VELO-SUAREZ, L., MAURER, D., BONNETON, P., CHARRIA, G., DUPUY, C. eta GENTIEN, P. 2013. «Distribution of Dinophysis species in the Bay of Biscay and possible transport pathways to Arcachon Bay». Journal of Marine Systems, 109-110, 273-283.

[49] BlanCO, J., ARÉVAlO, F., MOROÑO, Á., CORREA, J., MUÑÍZ, S., MARIÑO, C. eta MARTÍN, H. 2017. «Presence of azaspiracids in bivalve molluscs from Northern Spain». Toxicon, 137, 135-143.

[50] LAMAS, J.P., ARÉVALO, F., MOROÑO, Á., CORREA, J., MUÑIZ, S. eta BLANCO, J. 2019. «Detection and spatio-temporal distribution of pinnatoxins in shellfish from the Atlantic and Cantabrian coasts of Spain». Toxins, 11, 340.

[51] MUÑIZ, O., REVILLA, M., RODRÍGUEZ, J., LAZA-MARTÍNEZ, A., SEOANE, S., FRANCO, J. eta ORIVE, E. 2017. «Evaluation of phytoplankton quality and toxicity risk based on a long-term time series previous to the implementation of a bivalve farm (Basque coast as a case study)». Re gional Studies in Marine Science, 10, 10-19.

[52] BILBAO, J., MUÑIZ, O., RODRÍGUEZ, J. G., REVILLA, M., LAZAMARTÍNEZ, A. eta SEOANE, S. 2020. «Assessment of a sheltered euhaline area of the southeastern Bay of Biscay to sustain bivalve production in terms of phytoplankton community composition». Oceanologia, in press. 
[53] EDLER, L. eta ELBRÄCHTER, M. 2010. «Chapter 2: The Utermöhl method for quantitative phytoplankton analysis». In: KARLSON, B., CUSAK, C. eta BRESNAN, E. (Eds.). Microscopic and molecular methods for quantitative phytoplankton analysis. Paris: UNESCO, 55,13-20.

[54] SWAN, S. eta DAVIDSON, K. 2012. Monitoring programme for the presence of toxin producing plankton in shellfish production areas in Scotland. Annual report to Food Standards Agency.

[55] TAYLOR, A.H., GEIDER, R.J. eta GILBERT, F.J.H. 1997. «Seasonal and latitudinal dependencies of phytoplankton carbon-to-chlorophyll a ratios: results of a modelling study». Marine Ecology Progress Series, 152, 51-66.

[56] DOMINGUES, R.B., BARBOSA, A. eta GALVÃO, H. 2008. «Constraints on the use of phytoplankton as a biological quality element within the Water Framework Directive in Portuguese waters». Marine Pollution Bulletin, 56, 1389-1395.

[57] DOLMER, P. 2000. «Feeding activity of mussels Mytilus edulis related to near-bed currents and phytoplankton biomass». Journal of Sea Research, 44, 221-231.

[58] RIISGÅRD, H.U. 2001. «On measurement of filtration rates in bivalves-the stony road to reliable data: review and interpretation». Marine Ecology Progress Series, 211, 275-291.

[59] ORIVE, E., FRANCO, J., MADARIAGA, I. eta REVILLA, M. 2004. «Bacterioplankton and phytoplankton communities». BORJA, A. eta COLLINS, M. (Eds.), Oceanography and Marine Environment of the Basque Country. Elsevier, Amsterdam, The Netherlands, 367-393.

[60] VARELA, M., PREGO, R. eta PAZOS, Y. 2008. «Spatial and temporal variability of phytoplankton biomass, primary production and community structure in the Pontevedra Ria (NW Iberian Peninsula): oceanographic periods and possible response to environmental changes». Marine Biogy, 154, 483-499.

[61] SPYRAKOS, E., VILAS, L.G., PALENZUELA, J.M.T. eta BARTON, E.D. 2011. «Remote sensing chlorophyll a of optically complex waters (rias Baixas, NW Spain): Application of a regionally specific chlorophyll $a$ algorithm for MERIS full resolution data during an up- welling cycle». Remote Sensing of Environment, 115, 2471-2485.

[62] JOUENNE, F., LEFEBVRE, S., VÉRON, B. eta LAGADEUC, Y. 2007. «Phytoplankton community structure and primary production in small intertidal estuarine-bay ecosystem (eastern English Channel, France)». Marine Biology, 151, 805-825.

[63] KLEIN, C., CLAQUIN, P., BOUCHART, V., LE ROY, B. eta VÉRON, B. 2010. «Dynamics of Pseudo-nitzschia spp. and domoic acid production in a macrotidal ecosystem of the Eastern English Channel (Normandy, France)». Harmful Algae, 9, 218-226.

[64] TYBERGHEIN, L., VERBRUGGEN, H., PAULY, K., TROUPIN, C., MINEUR, F. eta DE CLERCK, O. 2012. «Bio-ORACLE: A global environ- 
Jone Bilbao, Oihane Muñiz, Marta Revilla, José Germán Rodríguez, Aitor Laza-Martínez, Sergio Seoane

mental dataset for marine species distribution modelling». Global Ecology and Biogeography, 21, 272-281.

[65] ASSIS, J., TYBERGHEIN, L., BOSCH, S., VERBRUGGEN, H., SERRAO, E. eta DE CLERCK, O. 2018. «Bio-ORACLE v2.0: Extending marine data layers for bioclimatic modelling». Global Ecology and Biogeography, 27, 277-284.

[66] REVILLA, M., FRANCO, J., BALD, J., BORJA, Á., LAZA, A., SEOANE, S. eta VALENCIA, V. 2009. «Assessment of the phytoplankton ecological status in the Basque coast (northern Spain) according to the European Water Framework Directive». Journal of Sea Research, 61, 60-67.

[67] ZORITA I., REVILLA M. eta GONZÁLEZ M. 2019. Informe final del proyecto: Operaciones de mantenimiento/desmantelamiento de la batea de $\mathrm{Mu}$ triku y long-lines de Mendexa (MALOTES II). Elaborado por AZTI para Gobierno Vasco. 58 pp.

[68] WALL, C.C., GOBLER, C.J., PETERSON, B.J. eta WARD, J.E., 2013. «Contrast-ing growth patterns of suspension-feeding molluscs (Mercenaria mercenaria, Crassostrea virginica, Argopecten irradians, and Crepidula fornicata) across a eutrophication gradient in the Peconic Estuary, NY, USA». Estuaries and Coasts, 36, 1274-1291.

[69] CATARINA, A. eta XAVIER, F. 2012. «Nutritional Value and Uses of Microalgae in Aquaculture». Aquaculture, 10, 59-78.

[70] MARTÍNEZ-PITA, I., SÁNCHEZ-LAZO, C., RUÍZ-JARABO, I., HERRERA, M. eta MANCERA, J.M. 2012. «Biochemical composition, lipid classes, fatty acids and sexual hormones in the mussel Mytilus galloprovincialis from cultivated populations in south Spain». Aquaculture, 358-359, 274-283.

[71] SÁNCHEZ-LAZO, C. eta MARTÍNEZ-PITA, I. 2012. Biochemical and energy dynamics during larval development of the mussel Mytilus galloprovincialis (Lamarck, 1819). Aquaculture, 358-359, 71-78.

[72] PARRISH, C. 2013. «Lipids in Marine Ecosystems». ISRN Oceanography, 2013, 1-16.

[73] VOLKMAN, J.K., JEFFREY, S.W., NICHOLS, P.D., ROGERS, G.I. eta GARLAND, C. D., 1989. «Fatty acid and lipid composition of 10 species of microalgae used in mariculture». Journal of Experimental Marine Biology and Ecology, 128, 219-240.

[74] VOLKMAN, J.K., DUNSTAN, G.A., JEFFREY, S.W. eta KEARNEY, P.S., 1991. «Fatty acids from microalgae of the genus Pavlova». Phytochemistry. 30, $1855-1859$.

[75] KNUCKEY, R., BROWN, M., BARRETT, S. eta HALLEGRAEFF, G. 2002. «Isolation of new nanoplanktonic diatom strains and their evaluation as diets for juvenile Pacific oysters (Crassostrea gigas)». Aquaculture, 211, 253-274.

[76] TROTTET, A., ROY, S., TAMIGNEAUX, E., LOVEJOY, C. eta TREMBLAY, R., 2008. «Impact of suspended mussels (Mytilus edulis L.) on plankton communities in a Magdalen Islands lagoon (Québec, Canada): a mesocosm approach». Journal of Experimental Marine Biology and Ecology, 365, 103-115. 
[77] EFSA, 2009. «Scientific opinion of the panel on contaminants in the food chain on a request from the European Commission on marine biotoxins in shellfish-domoic acid». European Food Safety Authority Journal, 1181, $1-61$.

[78] MERTENS, K. N., ADACHI, M., ANDERSON, D. M., BAND-SCHMIDT, C. J., BRAVO, I., BROSNAHAN, M. L. 2020. «Morphological and phylogenetic data do not support the split of Alexandrium into four genera». Harmful algae, 98, 101902.

[79] MOITA, M., PAZOS, Y., ROCHA, C., NOLASCO, R., eta OLIVEIRA, P. 2016. «Toward predicting Dinophysis blooms off NW Iberia: A decade of events». Harmful Algae, 53, 17-32.

[80] MAURER, D., BEC, B., NEAUD-MASSON, N., RUMEBE, M., AUBY, I. eta GRÉMARE, A. 2010. «Etude des relations entre le phytoplancton et les phénomènes de toxicité d'origine inconnue dans le Bassin d'Arcachon». Tâche T3b Du Programme National Arcachon (AFSSA): "Toxicité due à des espèces phytoplanctoniques réputées toxiques ou encore méconnues dans le Bassin d'Arcachon»: Rapport Ifremer RST/LER/AR/10.004.

[81] RUIZ-VILLARREAL, M., GARCÍA-GARCÍA, L., COBAS, M., DÍAZ, P. eta REGUERA, B. 2016. «Modelling the hydrodynamic conditions associated with Dinophysis blooms in Galicia (NW Spain)». Harmful Algae, 53, 40-52.

[82] REGUEIRO, J., ROSSIGNOLI, A., ÁLVAREZ, G. eta BLANCO, J. 2011. «Automated on-line solid-phase extraction coupled to liquid chromatography-tandem mass spectrometry for determination of lipophilic marine toxins in shellfish». Food Chemistry, 129, 533-540.

[83] RODRÍGUEZ, L., GONZÁLEZ, V., MARTÍNEZ, A., PAZ, B., LAGO, J., CORDEIRO, V., BLANCO, L., VIEITES, J.M. eta CABADO, A.G. 2015. «Occurrence of lipophilic marine toxins in shellfish from Galicia (NW of Spain) and synergies among them». Marine Drugs, 13, 1666-1687.

[84] GONZÁlEZ, M., SOLAUN, O., ZORITA, I., REVILLA, M., ANDRÉS, M., FRANCO, J., EPELDE, I., LIRIA, P., ASENSIO, J.L., RODRÍGUEZ, J.G., BALD, J., LAGOS, L.E., ARANTZAMENDI, L., LARRETA, J., MENCHACA, I., BORJA, A. eta VALENCIA, V. 2017. Sistemas innovadores de monitoreo para prevención de riesgos en zonas de producción de moluscos en mar abierto. AZTI-Tecnalia para Gobierno Vasco, Departamento de Desarrollo Económico y Competitividad, Vice. de Agricultura, Pesca y Políticas Alimentarias, Dirección de Pesca y Acuicultura.

[85] PARSONS, M., ALIGIZAKI, K., BOTTEIN, M., FRAGA, S., MORTON, S., PENNA, A., eta RHODES, L. 2012. «Gambierdiscus and Ostreopsis: Reassessment of the state of knowledge of their taxonomy, geography, ecophysiology, and toxicology». Harmful Algae, 14, 107-129.

[86] FAIMALI, M., GIUSSANI, V., PIAZZA, V., GARAVENTA, F., CORRÀ, C., eta ASNAGHI, V. 2012. «Toxic effects of harmful benthic dinoflagellate Ostreopsis ovata on invertebrate and vertebrate marine organisms». Marine Environmental Research, 76, 97-107. 
Jone Bilbao, Oihane Muñiz, Marta Revilla, José Germán Rodríguez, Aitor Laza-Martínez, Sergio Seoane

[87] BASTI, L., NAGAI, S., WATANABE, S., ODA, T. eta TANAKA, Y. 2016. «Neuroenzymatic activity and physiological energetics in Manila clam, $R u$ ditapes philippinarum, during short-term sublethal exposure to harmful alga, Heterocapsa circularisquama». Aquatic Toxicology, 176, 76-87.

[88] ESTRADA, N., DE JESÚS ROMERO, M., CAMPA-CÓRDOVA, A., LUNA, A. eta ASCENCIO, F. 2007. «Effects of the toxic dinoflagellate, Gymnodinium catenatum on hydrolytic and antioxidant enzymes, in tissues of the giant lions-paw scallop Nodipecten subnodosus». Comparative Biochemistry and Physiology, 146, 502-510.

[89] HABERKORN, H., TRAN, D., MASSABUAU, J.C., CIRET, P., SAVAR, V. eta SOUDANT, P. 2011. «Relationship between valve activity, microalgae concentration in the water and toxin accumulation in the digestive gland of the Pacific oyster Crassostrea gigas exposed to Alexandrium minutum». Marine Pollution Bulletin, 62, 1191-1197.

[90] MOROÑO, A., FRANCO, J., MIRANDA, M., REYERO, M.I. eta BLANCO, J. 2001. «The effect of mussel size, temperature, seston volume, food quality and volume-specific toxin concentration on the uptake rate of PSP toxins by mussels (Mytilus galloprovincialis Lmk)». Journal of Experimental Marine Biology and Ecology, 257, 117-132.

[91] RAMOS, V. eta VASCONCELOS, V. 2010. «Palytoxin and analogs: biological and ecological effects». Marine Drugs, 8, 2021-2037.

[92] BLANCO, J., CANO, J., MARIÑO, M. eta CAMPOS, M.J. 2006. Effect of phytoplankton containing paralytic shellfish and amnesic shellfish toxins on the culture of the king scallop Pecten maximus in Málaga (SE Spain). Aquatic Living Resources, 19, 267-273.

[93] SAMSON, J.C., SHUMWAY, S.E. eta WEIS, J.S. 2008. «Effects of the toxic dinoflagellate, Alexandrium fundyense on three species of larval fish: a foodchain approach». Journal of Fish Biology, 72, 168-188. 